\title{
O DWÓCH ODMIANACH WZORCÓW OSOBOWYCH W PRAWIE KARNYM
}

Proces przypisywania odpowiedzialności karnej ma to do siebie - choć być może jest to cecha prawa w ogólności - że mimo prób usystematyzowania i odpowiedniego ułożenia elementów tworzących wysublimowane konstrukcje dogmatyczne część z nich stosowana jest, przynajmniej do pewnego stopnia, intuicyjnie. Ten brak ścisłości skrywany bywa niekiedy odwołaniem do korygującej roli zdrowego rozsądku organu stosującego prawo, a zatem - w ostatecznym rozrachunku - konkretnego sędziego. Jakkolwiek zdrowy rozsądek jest narzędziem niewątpliwie przydatnym, bez obawy o popełnienie większego błędu przyjąć można, że rolą nauki prawa powinno być możliwie daleko idace doprecyzowanie podstaw pozwalajacych na pociagnięcie danej osoby do odpowiedzialności. Rzecz bowiem w tym, że jeśliby owa oczywistość czy zdroworozsądkowość okazała się kryterium jedynym, mogłaby na tym ucierpieć gwarancyjna funkcja prawa karnego.

Wydaje się, że do tego rodzaju intuicyjnie stosowanych konstrukcji zaliczyć można figury używane do prawnokarnego wartościowania zachowania ludzkiego na wielu płaszczyznach, nazywane wzorcami osobowymi. Ich „zdroworozsądkowość" ujawni się szczególnie wtedy, gdy zdamy sobie sprawę, że prawdopodobnie najczęściej powoływanym wzorcem osobowym jest standard rozsądnego człowieka czy obywatela ${ }^{1}$. W stosunku do osobowych figur porównawczych używa się niekiedy również pojęcia „postaci standardowych” (Maßstabfigur) ${ }^{2}$. Mateusz Rodzynkiewicz jako podstawowe obszary prawa karnego związane z problematyką wzorców osobowych określa przypisanie zachowaniu cechy nieumyślności w znaczeniu prawnokarnym (obejmując tym pojęciem również zachowanie należytej ostrożności), wyłączenie zawinienia, rozpoznawanie stanu niebezpieczeństwa oraz rozpoznawanie niektórych znamion ocennych ${ }^{3}$. Wobec tak szerokiego, potencjalnego „pola” zastosowania dla osobowych postaci porównawczych przyjąć można, że standard modelowego obywatela usłużnie pojawia się wszędzie tam, gdzie dostrzegamy poważniejszy problem nie tylko o charakterze dogmatycznym, ale i praktycznym, a niewykluczone, że również teoretycznym ${ }^{4}$. Nie można jednak zignorować tych głosów, które

${ }^{1}$ Zob. J. Kochanowski, Standard „rozsqdnego człowieka” $w$ prawie karnym, „Studia Iuridica” 20, 1991, s. 125 i n.

${ }^{2}$ Zob. K. Schmoller, Standardowe postacie w prawie karnym jako pomocniczy punkt odniesienia w ocenach prawnych, „Przegląd Prawa Karnego” 1992, nr 5, s. 43 i n.

${ }^{3}$ M. Rodzynkiewicz, Modelowanie pojęć w prawie karnym, Kraków 1998, s. 88-91.

${ }^{4}$ Używając określenia P. Zakrzewskiego, standard modelowego obywatela stanowi panaceum na większość problemów, na jakie natrafić można zarówno w analizie teoretycznej, dogma- 
postulują całkowite zrezygnowanie z osobowych postaci porównawczych właśnie z uwagi na ich niedookreśloność ${ }^{5}$.

Zaryzykować można jednak twierdzenie, że czymś zgoła odmiennym jest narzędzie w postaci wzorca używanego do ustalenia stanu świadomości potencjalnego sprawcy czynu zabronionego, czymśs odmiennym zaś - wzorzec używany dla określenia, czy sprawca taki spełnił wymagany od niego (na różnych zresztą płaszczyznach) standard. Źródeł owego rozróżnienia - pozwalającego na sformułowanie hipotezy o dwóch odmianach wzorców osobowych w prawie karnym - poszukiwać by należało na tej samej płaszczyźnie, na której dokonujemy podziału podstaw odpowiedzialności karnej. Spośród wielu możliwych do wyobrażenia i przeprowadzenia kategoryzacji szczególne znaczenie przedstawia podział - nawiąujacy do pojęć stosowanych w filozofii - na te o charakterze ontycznym oraz normatywnym (ocennym), a zatem nawiąujacy do sfer bytu i powinności. Pierwsze z nich dotyczyć będą pewnych elementów rzeczywistości, czyli faktów takich jak zewnętrzne zachowanie się podmiotu odpowiedzialności karnej oraz - również należącego do sfery faktycznej, przynajmniej w jego płaszczyźnie intelektualnej - stosunku psychicznego sprawcy do czynu; drugie stanowić będą wynik aplikacji ocen prawnych. O ile podstawa odpowiedzialności o charakterze ontycznym jest jedynie odtwarzana (rekonstruowana) z perspektywy ex post, o tyle podstawa normatywna jest kreowana - z uwzględnieniem najróżniejszych rozstrzygnięć ocennych - z perspektywy ex ante ${ }^{6}$. Trafne wydaje się w tym kontekście spostrzeżenie Michała Królikowskiego, że właściwą metodą ustalenia podstaw odpowiedzialności jest uwzględnienie zależności naturalnych (a zatem ontycznych), które następnie powinny być poddawane kwalifikacji normatywnej z uwzględnieniem teleologii prawnokarnej. Chodzi zatem zarówno o opis rzeczy, jak i o uwzględnienie ogólnych zjawisk społecznych ${ }^{7}$.

Wydawać by się mogło, że wzorce osobowe odnosić będą się wyłącznie do płaszczyzny normatywnej. Za ich pomoca określamy wszak przede wszystkim treść powinnego - a zatem dodatnie ocenianego z perspektywy obowiąujacego prawa - zachowania podmiotu odpowiedzialności karnej względem dobra przedstawiajacego wartość społeczna. Określamy zatem przede wszystkim, jak dany podmiot pow inien się zachować - a nie jak to uczynił w rzeczywistości, która stanowi jedynie płaszczyznę porównawczą - co stanowi niewątpliwie sąd o charakterze wartościującym, stanowiący pewną emanację oczekiwanego stanu rzeczy. Zauważmy jednak, że w procesie przypisywania odpowiedzialności karnej nieodzowne jest zrekonstruowanie przednormatywnej jej podsta-

tycznej, jak i w stosowaniu prawa, idem, Stopniowanie winy w prawie karnym, Warszawa 2016, s. 282 .

${ }^{5} \mathrm{M}$. Byczyk stwierdza nawet, że posługiwanie się tego rodzaju niedookreślonymi figurami stoi w sprzeczności z zasadami demokratycznego państwa prawnego, idem, Normy ostrożności w prawie karnym, Poznań 2016, s. 21 i 24.

${ }^{6}$ J. Giezek, P. Kardas, O kryteriach obiektywnego oraz subiektywnego przypisania z perspektywy podstaw odpowiedzialności karnej - uwagi wprowadzajace w: eidem (red.), Obiektywne oraz subiektywne przypisanie odpowiedzialności karnej, Warszawa 2016, s. 16.

${ }^{7}$ M. Królikowski, Kontekstowa teoria (dogmatyki) prawa karnego, „Studia Iuridica” 46, 2006, s. 196. 
wy w postaci zachowania ludzkiego, której elementem jest również w pewien sposób „ukryty” - znajdujący się bowiem „w głowie” sprawcy czynu zabronionego - stan jego świadomości ${ }^{8}$. Dopóki nie dysponujemy - a prawdopodobnie w dającym się przewidzieć czasie dysponować nie będziemy - żadnym środkiem pozwalającym na swoiste odtworzenie rzeczywistego stanu świadomości sprawcy czynu zabronionego, dopóty ustalenia w tym zakresie czynione muszą być w sposób odmienny. Używając obrazowego określenia Mikołaja Małeckiego organ procesowy nie jest w stanie „wejść” do głowy sprawcy i wydobyć stamtąd dowodu na świadomość określonego stanu rzeczy ${ }^{9}$. Wydaje się, że stosowanym w tym zakresie narzędziem jest właśnie wzorzec osobowy, przy budowaniu którego uwzględniamy również zewnętrzne zachowanie się sprawcy ${ }^{10}$. Ocenialibyśmy zatem - z jednej strony - z czego zdaje sobie sprawę przeciętny człowiek, znalazłszy się w sytuacji oskarżonego, oraz - z drugiej - na uświadomienie, jakich elementów stanu faktycznego wskazuje zachowanie sprawcy, dokładniej zaś jego dostosowanie do warunków sytuacyjnych. Nie wydaje się przy tym trafne ograniczenie użycia wzorca wyłącznie do przewidywania określonych przebiegów kauzalnych ${ }^{11}$, choć niewątpliwie w tym zakresie „wzorcowość” odnoszacca się do nieco bardziej skomplikowanych procesów kojarzenia jest bardziej namacalna. Z równie dobrym efektem osobowej figury porównawczej użyć możemy jednak do ustalenia stanu świadomości sprawcy odnoszącego się do okoliczności współczesnych podejmowanemu działaniu czy zaniechaniu. Załóżmy zatem w tym miejscu, że również na płaszczyźnie rekonstrukcji stanu świadomości sprawcy czynu zabronionego - ze względu na niemożliwość bezpośredniego dostrzeżenia tego elementu - odwołanie się do wzorca osobowego jest nieuniknione $^{12}$. Porównując konkretnego sprawcę z ogólnym ze swej istoty wzorcem, udzielalibyśmy odpowiedzi na pytanie, jak prawdopodobnie kształtował się stan jego świadomości w czasie wypełniania przedmiotowych znamion czynu zabronionego.

Można chyba zatem stwierdzić, że w prawie karnym posługujemy się wzorcem, który pomaga nam ustalić okoliczności przynależące zarówno do sfery bytu, jak i - w pewnej przynajmniej mierze do niej podobna - figura pozwalającą określić elementy, które skłonni bylibyśmy przyporządkować do sfery powinności. Wydaje się, że ta zasadnicza różnica - w sposób mniej lub bardziej wierny czerpiąca z filozofii, a zależna od punktu odniesienia wzorca osobowego - pozwala na wyodrębnienie dwóch zasadniczych odmian owych wzorców. Pierwszy z nich służyć będzie wyłącznie do rekonstrukcji fragmentu rzeczywi-

8 J. Giezek, P. Kardas, op. cit., s. 18.

${ }_{9}^{9}$ M. Małecki, Kryteria przypisania zamiaru wynikowego. Uwagi na marginesie wyroku Sadu Apelacyjnego w Krakowie z 29 kwietnia 2013 r. (II AKa 62/13), „Czasopismo Prawa Karnego i Nauk Penalnych" 2013, z. 3, s. 33.

${ }^{10} \mathrm{~W}$ szczególności wówczas, gdy z samej treści zachowania wnioskować możemy, że sprawca określony element rzeczywistości dostrzegł i wykorzystał. Zob. szerzej M. Laskowski, Ustalanie umyślności w praktyce orzeczniczej, w: J. Majewski (red.), Umyślność i jej formy, Toruń 2011, s. 51 i n.

${ }^{11}$ Tak, jak się zdaje, T. Kaczmarek, Sporne problemy umyślności, w: J. Majewski (red.), op. cit., s. 31.

${ }^{12}$ Por. J. Giezek, Świadomość sprawcy czynu zabronionego, Warszawa 2013, s. 160. 
stości. Używając go w procesie przypisywania odpowiedzialności karnej, nie będziemy zatem odpowiadać na pytanie, jak dany stan rzeczy powinien się przedstawiać, lecz jak - z większym lub mniejszym prawdopodobieństwem - de facto się on przedstawiał. Drugi z modeli - wręcz przeciwnie - służy do określenia spodziewanego (oczekiwanego), wartościowanego pozytywnie, lecz jedynie w y magan ego od podmiotu zachowania (względnie świadomości określonego stopnia niebezpieczeństwa związanego z przedsiębranym zachowaniem). Odpowiedzialność karną przypisywać będziemy zatem - w tym drugim przypadku - jedynie wówczas, gdy stan rzeczywisty nie pokrywa się ze stanem wymaganym. Będziemy mieli jednak do czynienia z pewną per s on ifikacja powinności, a nie-jak w przypadku pierwszym-rekonstrukcją rzeczywistości ${ }^{13}$.

Spostrzeżenie takie pozwala na dokonanie dość klarownego odróżnienia - nawiązującego do siatki terminologicznej stosowanej $\mathrm{w}$ teorii prawa ${ }^{14}$ - wzorca rekonstrukcyjnego od wzorca optymalizacyjnego. Pierwszy z nich odnosi się wyłącznie do sfery bytu - odpowiadając na pytanie, jak jest (jak było), drugi zaś do sfery powinności, pozwalając na rozstrzygnięcie, jak być powinno; ma on zatem charakter ocenny oraz postulatywny. Z tego też względu można go nazwać wzorcem normatywnym. O ile teoretycznoprawny model rekonstrukcyjny wyjaśniać ma rzeczywiste funkcjonowanie badanego zjawiska, o tyle model o podstawie normatywnej (model optymalizacyjny) - jest to „układ twierdzeń idealizacyjnych przedstawiający własności, które powinno mieć badane zjawisko, aby osiągnięty został cel o charakterze moralnym, ekonomicznym lub innym" ${ }^{15}$. Pierwszy z nich przedstawiać ma badane zjawisko takie, jakim ono jest przeciętnie spotykane w praktyce, drugi natomiast budowany jest na podstawie analizy treści norm prawnych z punktu widzenia wyznaczonych celów i zawiera ex definitione element ocenny. Celem wzorca rekonstrukcyjnego będzie zatem jak najwierniejsze odwzorowanie rzeczywistości, celem normatywnego zaś - jej odpowiednie kształtowanie. Wzorzec rekonstrukcyjny jedynie odtwarza rzeczywistość, optymalizacyjny już ją w pewnym zakresie projektuje czy programuje.

Zauważmy, że powyższy podział Andrzeja Malinowskiego i Leszka Nowaka na model rekonstrukcyjny i postulatywny nie w pełni pokrywa się z zaproponowanym swego czasu przez Mateusza Rodzynkiewicza podziałem wzorców w ścisłym sensie modelu na modele-wzory i modele-odwzorowania ${ }^{16}$. $\mathrm{O}$ ile pojęciu modelu-wzoru w znacznej mierze odpowiada wzorzec optymalizacyjny (normatywny), o tyle wydaje się, że wzorzec rekonstrukcyjny - według terminologii A. Malinowskiego i L. Nowaka - nie stanowi prostego „prze-

${ }_{13}$ Por. K. Lipiński, Granice obiektywizacji odpowiedzialności karnej-perspektywa wzorców osobowych, w: M. Pajakk, R. Zawłocki (red.), Prawo karne wobec konstytucji, Warszawa 2018, s. 35-36.

14 A. Malinowski, L. Nowak, Problemy modelowania w teorii prawa, „Państwo i Prawo” 1972, z. 2 , s. 93 .

${ }^{15}$ Ibidem, s. 91. Dodajmy w tym miejscu, że z uwagi na fakt skodyfikowania znacznej części reguł ostrożności (czego klasycznym przykładem są reguły zawarte w ustawie - Prawo o ruchu drogowym), w niektórych przypadkach istotne będą również względy o charakterze tetycznym.

16 M. Rodzynkiewicz, op. cit., s. 12. 
brania” dla modelu-odwzorowania. W szczególności nie stanowi on żadnego przedmiotu indywidualnego schematycznie odwzorowującego strukturę innego typu ${ }^{17}$ - takim „przedmiotem indywidualnym” jest dopiero świadomość konkretnego sprawcy czynu zabronionego, finalnie ustalona za pomoca wzorca. Paradoksalnie wzorcowi rekonstrukcyjnemu bliżej byłoby zatem - mimo realnego odniesienia - do modelu-wzoru, skoro miałby on prowadzić do sprecyzowania owego indywidualnego „przedmiotu” w postaci świadomości z imienia i nazwiska określonego sprawcy. Wydaje się, że stan świadomości takiego sprawcy ustalany będzie raczej za pomoca narzędzia nazywanego przez M. Rodzynkiewicza wzorcem w sensie deskryptywnym (behawioralnym). Stanowi on w statystyce jednostkę typową oraz jest równoznaczny pojęciu standardu rozumianego jako „przeciętny typ” w ujęciu statystycznie doniosłego nasilenia - bez jakichkolwiek elementów o charakterze normatywnym, w szczególności dotyczących stawianych przed sprawcą wymagań ${ }^{18}$. Warto zauważyć, że utożsamienie wzorca używanego do rekonstrukcji stanu świadomości sprawcy czynu zabronionego z wzorcem w sensie deskryptywnym (behawioralnym) koresponduje z określeniem teoretycznoprawnego modelu rekonstrukcyjnego, który „przedstawia taki badany proces i takie jego rozumienie, jakie sa przeciętnie spotykane w praktyce"19. Model rekonstrukcyjny byłby zatem pomocniczym narzędziem przybliżonego uogólniania badanych zjawisk.

Aby unaocznić praktyczną doniosłość rozróżnienia wzorca rekonstrukcyjnego i wzorca optymalizacyjnego, zauważmy, że czym innym jest:

1) obiektywnie ujmowana przewidywalność (rozpoznawalność) wypełnienia znamion czynu zabronionego,

2) przewidywalność (możliwość przewidzenia) ujmowana subiektywnie a zatem relatywizowana do konkretnego sprawcy - która bynajmniej z przewidywalnością obiektywną pokrywać się nie musi,

3) rzeczywiste przewidzenie możliwości wypełnienia znamion,

4) usprawiedliwienie niemożliwości przewidzenia popełnienia czynu zabronionego.

Nietrudno zauważyć, że okoliczności te - z perspektywy zagadnienia odniesienia wzorca osobowego - nie sa jednolite. Niektóre z nich mają bowiem charakter wyłącznie ontyczny, niektóre zaś normatywny. W praktyce oznaczać to będzie, że niektóre $\mathrm{z}$ nich należy odtworzyć $\mathrm{w}$ ramach reasumpcji materiału dowodowego, inne zaś stanowić będą jedynie schemat, z którym porównać należy zrekonstruowany fragment rzeczywistości. Dostrzeżenie tej różnicy będzie doniosłe szczególnie wtedy, gdy odpowiedzialność karna sprawcy zależy od umyślnego wypełnienia znamion, a zatem ustalenia, że w istocie zdawał on sobie sprawę z pewnej zależności, a nie jedynie tego, że z uwagi na przynależność do określonej grupy społecznej powinien mieć jej świadomość. Trudno

${ }_{17}$ Taki wymóg przed modelem-odwzorowaniem stawia I. Dąmbska, Dwa studia $z$ teorii naukowego poznania, Toruń 1962, s. 22-23.

${ }^{18}$ M. Rodzynkiewicz, op. cit., s. 12.

19 A. Malinowski, L. Nowak, op. cit., s. 93. 
jednocześnie zaprzeczyć występującemu w tym zakresie swego rodzaju sprzężeniu zwrotnemu, wyrażającemu się w rzutowaniu wzorca optymalizacyjnego na rekonstrukcyjny i odwrotnie.

Zastanowić należałoby się również nad tym, jakiego typu rozumowanie, czy być może nawet głębsza idea, może być użyte do próby wyjaśnienia tego, czym oba wzorce się charakteryzują. Będzie to zatem próba odpowiedzi na pytanie nie tyle o to, jak się szczegółowo przedstawia struktura wzorca rekonstrukcyjnego i normatywnego, ile co stanowi „budulec” obu z nich. Problematyka owego budulca jest zarazem pierwszym $\mathrm{z}$ aspektów, w jakim widoczny będzie dychotomiczny podział wzorców. Warto zauważyć, że skoro wzorzec rekonstrukcyjny jest miarą pewnej przeciętności, normatywny zaś - personifikacją wymagań czy oczekiwań, na płaszczyźnie językowej z pierwszym z nich łączyć będziemy raczej określenia aksjologicznie neutralne typu „przeciętny” czy „typowy”, z drugim zaś sugerujące pozytywne wartościowanie, a zatem np. „dobry”, „rozważny” czy „staranny”.

Zauważyć warto, że wzorzec - zarówno rekonstrukcyjny, jak i normatywny - konstruowany i wykorzystywany będzie przez organ stosujący prawo, a zatem przede wszystkim przez sędziego ${ }^{21}$. To on będzie zatem stosować procedurę myślowa pozwalająca na wytworzenie modelu oraz jego zaaplikowanie w konkretnym przypadku. W pewnym sensie można by stwierdzić, że organ stosujacy prawo każdorazowo konstruuje swój wzorzec, który następnie używany jest do przypisania odpowiedzialności karnej sprawcy. Powstać może w związku z tym pewne niebezpieczeństwo polegajace na zbytnim odbieganiu od siebie poszczególnych - używanych przez różnych sędziów - figur porównawczych. Rozumowanie sędziego poddawane będzie jednak kontroli przez sąd odwoławczy, „nakładajacy” na przedstawiony stan faktyczny wypracowany przez siebie schemat. Zarówno wzorzec rekonstrukcyjny, jak i normatywny składać będą się zaś nie tylko z wiedzy o charakterze potocznym czy też zdroworozsądkowym, ale niejednokrotnie uzupełniane będą wiedzą ekspercką.

Przypomnijmy, że wzorzec rekonstrukcyjny pomagać będzie w ustaleniu, z czego zazwyczaj zdaje sobie sprawę sprawca czynu zabroni o n e g o. Już takie stwierdzenie, odwołujące się do prawidłowości o charakterze statystycznym, kryje w sobie założenie o pewnej bazie wiedzy stanowiącej podstawę do skonstruowania modelu. Pojawić się musi zatem pytanie o to, jak i zgodnie z jakimi zasadami owa wiedza miałaby być gromadzona oraz - w dalszej kolejności - wykorzystywana. W pewnym uproszczeniu przyjąć można, że pośród elementów pozwalających na wytworzenie wzorca rekonstrukcyjnego znajdą się trzy czynniki:

${ }^{20}$ Niewykluczone jednak, że określenia implikujące pozytywne wartościowanie pojawią się również przy ustalaniu stanu świadomości sprawcy czynu zabronionego, lecz tylko wtedy, gdy stwierdzimy, że podmiot, któremu przypisujemy odpowiedzialność karna, w rzeczywistości cechy takie spełnia.

${ }^{21}$ Rekonstrukcji swojego stanu świadomości dokonywać może - skądinąd zapewne również w sposób probabilistyczny, choć opatrzony mniejszym niebezpieczeństwem błędu - sam sprawca. Nie będzie tego jednak oczywiście czynił, używając zgeneralizowanego wzorca, lecz opierając się na własnych wspomnieniach i doświadczeniach. 
1) doświadczenie życiowe sędziego,

2) będące składnikiem powszechnej wiedzy informacje o funkcjonowaniu ludzkiej psychiki, w szczególności co do procesów spostrzegania i przewidywania,

3) informacje o charakterze specjalistycznym, w praktyce włączane w nurt procesu karnego przez opinie biegłych.

Przyjrzyjmy się zatem pokrótce każdemu z tych elementów. Biorąc pod uwagę, że jako interesujaca $\mathrm{z}$ tej perspektywy jawi się wiedza organu stosujacego prawo, wydaje się, że podstawy do rekonstrukcji oraz ewentualnej oceny poprawności wytworzenia i zaaplikowania wzorca osobowego poszukiwać można by w przepisach Kodeksu postępowania karnego. Podstawę taką stanowić mógłby art. 7 k.p.k. w tym fragmencie, w którym wspomina o wiedzy i doświadczeniu życiowym organów postępowania. Zarówno wiedza, jak i doświadczenie życiowe pełnią rolę tzw. kluczy inferencyjnych, stanowiących element pewnego materiału porównawczego - zespołu twierdzeń, z którymi porównywane są twierdzenia dowodowe ${ }^{22}$. To zatem ów zespół twierdzeń stanowiłby wspomnianą bazę wiedzy. Co szczególnie istotne, w literaturze podkreśla się, że oceny wiarygodności źródła dowodowego dokonuje się przez „porównanie źródła dowodowego z "wzorcami« tego rodzaju źródeł dowodowych zakodowanymi przez podmiot dokonujacy oceny"; model taki wywodzi się z koncepcji wnioskowania indukcyjnego ${ }^{23}$, polegającego na dojściu do wniosku ogólnego, że każdy przedmiot danego rodzaju ma określoną cechę, na podstawie wielu przesłanek jednostkowych, stwierdzających, iż poszczególne przedmioty cechę taką posiadają ${ }^{24}$. Spostrzeżenie takie zdaje się idealnie wpasowywać w proces

${ }^{22}$ F. Przybylski-Lewandowski, Pojęcie wskazań wiedzy i doświadczenia życiowego jako kryterium uzasadniania decyzji stosowania prawa a bezpieczeństwo prawne, „Gdańskie Studia Prawnicze" 9, 2002, s. 100.

${ }^{23}$ Ibidem, s. 110. Dla porządku warto odnotować krytykę rozumowania indukcyjnego wyrażającą się m.in. w stwierdzeniu, że prawdziwości zdań uniwersalnych nie można wyprowadzić z doświadczenia; zdać sprawę z doświadczenia może jedynie zdanie jednostkowe, nie zaś uniwersalne. Zob. K. Popper, Logika odkrycia naukowego, Warszawa 2002, s. 22 i n. Rozumowanie indukcyjne, o którym tutaj mowa, miałoby chyba charakter zdroworozsądkowy. Zdroworozsądkowy problem indukcji wyraża się zaś w tym, że w drodze powtarzanych obserwacji w przeszłości formułujemy pewne oczekiwania i mocno wierzymy w pewne prawidłowości. Zdrowy rozsądek bierze za pewnik, że nasza wiara w prawidłowości jest uzasadniona przez powtarzające się obserwacje, które są odpowiedzialne za jej genezę - wierzymy, że słońce wzejdzie jutro, ponieważ działo się tak w przeszłości. K. Popper, Wiedza obiektywna. Ewolucyjna teoria epistemologiczna, Warszawa 2012, s. 11. Zaznaczmy jednak, że fakt posługiwania się pewnym modelem (tu: rekonstrukcyjnym) pozwala na przejście do porządku dziennego nad przypadkami niespełniającymi wzorca, skoro naszym celem jest w tej sytuacji określenie tego, jak rzeczywistość przedstawia się zazwyczaj (przeciętnie, statystycznie), nie zaś każdorazowo.

${ }^{24}$ Zob. Z. Ziembiński, Logika praktyczna, Warszawa 2014, s. 184. Byłaby to przy tym - w opisywanym przypadku - indukcja niezupełna. Skoro zaś mowa o indukcji, warto wspomnieć również o innym rodzaju zawodnego, twórczego rozumowania, jakim jest rozumowanie abdukcyjne. Abdukcja jest strategią dokonywania przypuszczeń i domysłów, która rozważa potencjalne hipotezy i wybiera niektóre spośród nich, aby poddać je dalszej analizie. Polega ona na generowaniu hipotez, wybieraniu spośród nich najbardziej obiecujących i testowaniu ich - jest zatem i w nauce, i w życiu codziennym jednym z kluczowych typów aktywności poznawczej. Zob. szerzej M. Urbański, Rozumowania abdukcyjne. Modele i procedury, Poznań 2009, s. 21. 
tworzenia czy - ujmując problem z drugiej niejako strony - wyjaśniania rekonstrukcyjnego wzorca osobowego. Wiedza i doświadczenie życiowe sędziego pozwalają mu bowiem na wytworzenie wzorca najbardziej prawdopodobnego stanu świadomości sprawcy czynu zabronionego, z którym porównywane sa twierdzenia o fakcie - rzeczywistości odbijającej się w umyśle konkretnego już sprawcy. Z perspektywy dowodowej im bardziej - biorac za podstawę wyjaśnienia oskarżonego - oddalać będziemy się od wzorca o charakterze rekonstrukcyjnym, tym mniej relacja ta będzie prawdopodobna (wiarygodna). W tym kontekście można by zapewne stwierdzić, że doświadczenie życiowe sędziego ma w pewnym sensie działanie dwukierunkowe. $\mathrm{Z}$ jednej bowiem strony determinuje kształt wypracowanego przez danego sędziego modelu rekonstrukcyjnego, z drugiej zaś powoduje, że twierdzenia odbiegajace radykalnie od owego wzorca uznane zostana za niewiarygodne. Ostatecznie może zatem dojść do sytuacji, w której wzorzec uzyska przewagę nad relacją konkretnego sprawcy, o ile nie ujawnią się okoliczności pozwalające na stwierdzenie, że in concreto dojść mogło do deformacji w zakresie jego procesów poznawczych. Można zatem stwierdzić, że na podstawie napływających danych orzekajaccy w sprawie sędzia wnioskuje o innych właściwościach spostrzeganej osoby; w psychologii prawidłowość taka określana jest niekiedy - znanym w innym nieco kontekście również w naukach prawnych - wnioskowaniem inferencyjnym ${ }^{25}$.

Drugi z powyżej wskazanych elementów stanowi w istocie pewną uogólnioną (a tym samym - uproszczona) wiedzę co do funkcjonowania procesów poznawczych. Element ten wiązać będzie się ściśle z doświadczeniem życiowym sędziego. Trudno bowiem uciec od stwierdzenia, że rekonstrukcję tego, w jaki sposób inne osoby spostrzegają rzeczywistość, w dużej mierze opierać musimy na własnych doświadczeniach. W tym kontekście przydatne może się okazać odwołanie do poruszanej w kognitywistyce problematyki tzw. psychologii potocznej (folk psychology, common sense psychology), utożsamianej niekiedy ze zdroworozsądkowym rozumieniem zjawisk psychicznych. Stanowi ona pewna aprioryczną ramę pojęciowa, służącą m.in. do odgadywania myśli i pragnień innych ludzi. Byłby to system przekonań dotyczących natury ludzkiej oraz natury świata, w jakim żyjemy, kształtowany jawnie lub w sposób ukryty, począwszy od wczesnego dzieciństwa ${ }^{26}$. Istnieje również możliwość interpretacji, zgodnie z którą psychologia potoczna stanowi zewnętrzną systematyzację (a nie wewnętrzny mechanizm), jaką psychologowie narzucają na złożone i bardziej dynamiczne codzienne praktyki społeczne ${ }^{27}$. Zasadniczy problem polega na tym, że wiedzę o innych ludziach czerpiemy na podstawie interpretacji zachowań tego, co widzimy i słyszymy, oraz tego, co wcześniej wiemy o ludziach i rzeczach. Rzecz jednak w tym, że wiedzy takiej „nie da się łatwo podsumować, wypojęciować, albowiem mamy do czynienia z wiedzą przedteoretyczna, która posiedliśmy w wyniku relacji z innymi i szeroko pojętych prak-

${ }^{25}$ Zob. szerzej J. Giezek, op. cit., s. 37-42 oraz 151-152 wraz ze wskazaną tam literatura.

26 W. Łukaszewski, Psychologia podzielona, „Nauka” 2011, nr 4, s. 9-11.

27 A. Kapusta, Problem intersubiektywności w świetle współczesnej neurokognitywistyki: od neuronów lustrzanych po narrację, „Studia Philosophiae Christianae” 2008, nr 2, s. 128. 
tyk społecznych" 28 . W skład owej uproszczonej wiedzy o mechanizmach psychologicznych wchodzić będą również takie powszechnie wiadome zależności, z którymi orzekajacy w sprawie sędzia bynajmniej samodzielnie zetknaćc się nie musiał, lecz ich wpływ na spostrzeganie (lub wnioskowanie) jawi się jako powszechnie znany. Uwaga ta dotyczyć będzie np. wpływu różnego rodzaju substancji psychotropowych na organizm ludzki.

Wydawać by się mogło, że wiedza specjalistyczna - jako odnosząca się zazwyczaj do przypadków wyjątkowych - nie będzie przydatna do budowy wzorca odpowiadającego na pytanie, jak dane zjawisko zazwyczaj się przedstawia. Trafne wydaje się jednak spostrzeżenie, że zaistnieje w tym przypadku wpływ niejako pośredni. Przez odpowiednio częsty kontakt organu orzekającego z wiadomościami specjalnymi na temat nieco bardziej złożonych procesów poznawczych zmienić może się bowiem obraz wiedzy i doświadczenia życiowego sędziego odnoszący się również do sytuacji typowych. Zarazem wiedza w tym zakresie nabierać będzie charakteru nieco bardziej specjalistycznego, zapewne absorbując pewne elementy $\mathrm{z}$ - przeciwstawianej psychologii potocznej psychologii naukowej ${ }^{29}$.

Próbę poszukiwania sposobu rozumowania pozwalającego na zbudowanie lub wyjaśnienie wzorca o charakterze rekonstrukcyjnym należałoby zatem zwieńczyć stwierdzeniem, że model ów budowany jest przede wszystkim na zasadzie pewnej uproszczonej indukcji. Zastosowanie znalazłoby zapewne również rozumowanie o charakterze abdukcyjnym. Normatywnej zaś ich podstawy doszukiwać można by się w art. 7 k.p.k. w zakresie, w jakim przepis ten wspomina o wiedzy i doświadczeniu życiowym organu postępowania.

Wzorzec normatywny (powinnościowy) nie odpowiada już na pytanie, jak rzeczywistość się przedstawia, lecz jak chcielibyśmy, aby się (modelowo) przedstawiała. Dodajemy w tym przypadku pewien pierwiastek celowościowy, a w niektórych przypadkach wręcz aksjologiczny (kryminalno-polityczny), który w sposób dość istotny ograniczać będzie falsyfikowalność modelu przez przypadki do niego niedorastające. Posługując się przykładem gdyby, czysto hipotetycznie rzecz ujmujac, badania empiryczne wykazały, że ponad 50\% chirurgów nie myje rak przed dokonaniem operacji, nie zmieniłoby to naszego oczekiwania co do dochowania takiego standardu; nasz wzorcowy „rzetelny chirurg” mimo to ręce by umył ${ }^{30}$. Wzorzec optymalizacyjny nie jest więc kreowany za pomoca prostej generalizacji. Nie wydaje się zatem, aby powstawał wyłącznie przez zastosowanie rozumowania indukcyjnego. Przypisując odpowiedzialność karna, orzekający w sprawie sąd nie odpowiada bowiem na pytanie, czy oskarżony zachował się tak, jak zazwyczaj zachowuja się przedstawiciele danej grupy w sytuacji porównywalnej z ta, która stała się przedmiotem zarzutu (niewykluczone zresztą, że odpowiedź musiałaby być wówczas pozytywna). Poszukuje on raczej odpowiedzi na pytanie, jak podmiot taki powinien się zachować. Odpowiedź wymaga odwołania się do pewnych

${ }^{28}$ Ibidem, s. 130.

${ }^{29}$ W. Łukaszewski, op. cit., s. 12-13. Zaznaczmy jeszcze, że oprócz psychologii potocznej i naukowej wyróżnia się psychologię jako praktykę społeczną.

30 K. Lipiński, op. cit., s. 36. 
społecznych oczekiwań, których emanację - zgodnie z przyjętymi tu założeniami - stanowi właśnie model optymalizacyjny. Konstrukcję wzorca normatywnego wytłumaczyć należy zatem w inny sposób niż w przypadku wzorca rekonstrukcyjnego. Z pewnością nie wystarczy w tym przypadku statystyczne „uśrednienie” przedstawicieli określonej grupy - gdyż tworzyłoby ono obraz tego, jak jest, a nie tego, jak być powinno. Proste stwierdzenie stanu faktycznego jest zatem z perspektywy wzorca normatywnego dalece niesatysfakcjonujące. W szczególności rzecz przedstawiałaby się tak wówczas, gdyby - jak wskazuje powyższy przykład chirurga - stan rzeczywisty nie pokrywał się ze stanem oczekiwanym.

Poszukiwać należy zatem - przynajmniej pomocniczo - jakiegoś odmiennego sposobu wyjaśniania. Atrakcyjna okazać się w tym kontekście może koncepcja idealizacji, do pewnego stopnia tolerująca oderwanie powinnego standardu od rzeczywistości ${ }^{31}$. Wstępnym jej założeniem jest bowiem nieodzowne $\mathrm{w}$ toku poznania naukowego tworzenie kontrfaktycznych założeń idealizacyjnych, których kolejno następujące po sobie uchylanie zbliża nas dopiero do rzeczywistości ${ }^{32}$. Leszek Nowak posługuje się m.in. przykładem praw opisujących spadanie ciał, dowodząc, że opierają się one na kontrfaktycznych założeniach idealizujących, pozwalających stworzyć twierdzenia idealizacyjne, które jednak wciąż nie znajdują zastosowania do bytów realnych. Z twierdzeń natomiast można - w drodze konkretyzacji - wyprowadzić bardziej już realistyczne formuły, uwzględniające niektóre z pominiętych czynników. Można by było mieć jednak wątpliwości co do możliwości przeniesienia tej metodologii - odnoszącej się zarówno do ogólnie ujętej nauki, jak i do rozumowania prawniczego - na grunt prawa karnego, a dokładniej: na szczegółowe zagadnienie wzorców osobowych. Prawo karne nie służy jednak poznaniu zachowania człowieka, lecz prowadzić ma do oceny określonego czynu i przypisania odpowiedzialności jego sprawcy. W szczególności zastrzeżenie to odnosić będzie się właśnie do wzorca normatywnego, którego nie używamy po to, aby określony fakt poznać (ustalić), lecz aby fakt już ustalony - skądinąd m.in. za pomocą wzorca rekonstrukcyjnego - ocenić przez porównanie z pewnym ideałem. Próba „przeszczepienia” koncepcji idealizacji oraz leżącej u jej podstaw interpretacji humanistycznej na grunt prawa karnego została już jednak podjęta przez Wojciecha Patryasa, który wychodzi z założenia, że „interpretacja czynu zabronionego okazuje się [...] zabiegiem prawnokarnie doniosłym, stanowiąc jedną z kluczowych operacji poznawczych przeprowadzanych w trakcie postę-

${ }^{31}$ Nie może być to jednak oderwanie całkowite, z tego też względu nawet $\mathrm{w}$ tym przypadku doświadczenie życiowe, pozwalające na wytyczenie granicy możliwości (realności) spełnienia wzorca, okaże się nieodzowne. Całkowicie bezużyteczny byłby wszak zarówno wzorzec wyznaczający standard niemożliwy do spełnienia, jak i taki, który byłby spełniony przez każdego sprawcę z nim porównywanego.

${ }^{32}$ Potraktowanie koncepcji idealizacji w tak skrótowy sposób stanowi oczywiście zbyt daleko idące uproszczenie. Kwestia ta opisana jest kompleksowo w pracach L. Nowaka: Próba metodologicznej charakterystyki prawoznawstwa, Poznań 1968; Interpretacja prawnicza. Studium z metodologii prawoznawstwa, Warszawa 1973; Wstęp do idealizacyjnej teorii nauki, Warszawa 1977; O ukrytej jedności nauk spotecznych i nauk przyrodniczych, „Nauka” 1998, nr 1, s. 11 i n. 
powania karnego"33. Jej efektem jest stworzenie zasady legalnej racjonalności, składającej się z ośmiu założeń idealizacyjnych, z których każde jest następnie uchylane w drodze konkretyzacji.

Zastrzec również należy, że wystapienie przypadku niespełniającego modelu nie powoduje falsyfikacji postulatów (elementów konstrukcyjnych) określonego wzorca, lecz oznacza, że nie zastosujemy modelu do owego konkretnego przypadku. Niefalsyfikowalność wzorca przez przypadek niespełniający jego wymagań nie oznacza jednak bynajmniej, że z rozumowania indukcyjnego mielibyśmy - tworząc modele normatywne oraz posługując się nimi - całkowicie zrezygnować. Wydający w sprawie orzeczenie sędzia nie może przecież poprzestać na niczym niepopartym wyobrażeniu oczekiwanego, a zarazem wartościowanego pozytywnie zachowania - przykładowo - osoby kierujacej pojazdem czy lekarza.

Jakkolwiek wszelkie stosowane w prawie karnym wzorce osobowe zaliczyć można do kategorii terminów teoretycznych (a zatem takich, które nie oznaczają fizycznych obiektów obserwowalnych) - od terminów takich można wymagać, aby miały one kryteria empirycznej stosowalności ${ }^{34}$. Aby wzorzec „rozważnego kierowcy” skonstruować (czy wymodelować), potrzebna jest przeto pewna baza wiedzy czy doświadczenia o charakterze empirycznym. Taka zaś baza budowana jest na podstawie przypadków, z którymi orzekający sędzia już się spotkał w ramach swego doświadczenia życiowego, poddanych pewnemu - zapewne uproszczonemu - uogólnieniu na takich samych zasadach, na jakich czyni się to w stosunku do wzorca rekonstrukcyjnego. Przyjąć można bowiem, że wzorce normatywne składają się zarówno z elementów o charakterze deskryptywnym jak i wartościującym, choć element rekonstrukcyjny potrzebny jest w zasadzie jedynie po to, aby wzorzec normatywny możliwy był do spełnienia. Innymi słowy, mimo idealizacyjnego charakteru wzorca optymalizacyjnego, opierać musi się on na pewnej podbudowie empirycznej, rzutującej na rzeczywistą możliwość spełnienia narzuconego standardu. Konstruujac wzorzec osobowy - w szczególności zaś jego elementy deskryptywne - nie sposób bowiem uciec od rozumowania indukcyjnego (co jednak przecież opisywanej idealizacji nie eliminuje), sprowadzającego się do odwołania do doświadczenia życiowego, rozpatrując zaś konkretną sprawę do modelu tego się odwołujemy, próbując przeprowadzić rozumowanie o charakterze odwrotnym, polegające na dopasowaniu jednostkowego przypadku do wzorca. Ujmując tę kwestię nieco innymi słowami: w toku ustalania odpowiedzialności karnej nieuniknione jest rozumowanie od szczegółu do ogółu - prowadzące do wytworzenia pewnego modelu (względnie następczego odwołania się do modelu już wytworzonego) - oraz skierowane w odwrotnym kierunku rozumowanie od ogółu do szczegółu - prowadzące z kolei do zaaplikowania modelu do konkretnego przypadku.

${ }^{33}$ W. Patryas, Interpretacja karnistyczna. Studium metodologiczne, Poznań 1988, s. 77.

34 L. Nowak, Próba metodologicznej..., s. 63. 
Zaznaczyć warto, że w przypadku wzorca normatywnego konieczne będzie uwzględnienie pierwiastka o charakterze celowościowym czy wręcz aksjologicznym (kryminalnopolitycznym), który wymyka się prostemu (zdroworozsądkowemu) wnioskowaniu indukcyjnemu. Być może to ten właśnie element wpływa na to, że posługując się wzorcami normatywnymi niektóre założenia idealizacyjne traktujemy jako niewzruszalne. Względy kryminalnopolityczne przesądzaja zatem o tym, że pozostajemy na pewnym poziomie oderwanego od rzeczywistości ideału, nie zbliżając go już do rzeczywistości. Ustalenie takiego poziomu stanowi rozstrzygnięcie o poziomie wymagań kierowanych do podmiotu podlegającego odpowiedzialności karnej. Niespełnienie standardu nawet przez statystycznie ujmowaną większość potencjalnych sprawców - nie wpłynie jeszcze samo przez się na obniżenie wymagań. Można by zatem przyjąć, że pomocniczy charakter próby wyjaśnienia budulca wzorca normatywnego za pomocą idealizacji wyraża się w tym, iż w pewnym momencie - osiagajacc pewien kryminalnopolitycznie uzasadniony poziom oczekiwań kierowanych do potencjalnego podmiotu odpowiedzialności karnej - rezygnujemy z dalszego „zbliżenia” modelu do rzeczywistości.

Powyższe rozważania prowadzą do wniosku, że pojawiające się w rozważaniach teoretycznych i dogmatycznych, jak również w orzecznictwie sądowym $^{35}$ odwołania do wzorca osobowego nie zawsze charakteryzuja się jednolitym punktem odniesienia. Różnica jest tymczasem niebłaha. Mamy bowiem do czynienia z dwoma rodzajami wzorców osobowych, które różni zarówno sposób konstrukcji, jak i aplikacji, co z kolei ma bezpośrednie przełożenie na odmienną procedurę dokonywania ustaleń w zakresie świadomości sprawcy czynu zabronionego (gdzie używamy wzorca rekonstrukcyjnego) lub zaktualizowania się - określanych niekiedy wstępnymi warunkami normowania ${ }^{36}$ - obiektywnej przewidywalności popełnienia czynu zabronionego oraz idącego z nim w parze obowiązku dochowania odpowiedniego standardu postępowania względem dobra przedstawiającego wartość społeczną (co z kolei określamy, oceniając zachowanie sprawcy przez pryzmat wzorca optymalizacyjnego).

dr Konrad Lipinski

Uniwersytet Wroctawski

konrad.lipinski@uwr.edu.pl

${ }^{35}$ Zob. P. Kardas, Sporne problemy wyktadni przestepstwa nadużycia zaufania, „Czasopismo Prawa Karnego i Nauk Penalnych” 2006, z. 2, s. 120-121. Zob. też np. wyrok SA w Lublinie z 18 sierpnia 2010 r., II AKa 186/10, „Krakowskie Zeszyty Sądowe” 2011, nr 10, poz. 47. Por. jednak ustalenia M. Byczyka, op. cit., s. 407.

${ }^{36}$ Dotyczy to w szczególności naruszenia zasad ostrożności. Zob. S. Tarapata, Obiektywna czy subiektywna przewidywalność? Gtos w sprawie sporu dotyczqcego nieświadomej nieumyślności, „Czasopismo Prawa Karnego i Nauk Penalnych” 2015, z. 1, s. 75 i n.; Ł. Pohl, Niezachowanie wymaganej ostrożności - znamię typu czynu zabronionego czy odrębny element $w$ strukturze przestẹstwa?, w: J. Majewski (red.), Nieumyślność, Toruń 2012, s. 81; idem, Struktura normy sankcjonowanej w prawie karnym. Zagadnienia ogólne, Poznań 2007, s. 101. 


\section{ABOUT TWO TYPES OF PERSONIFIED MODELS IN CRIMINAL LAW}

\section{Sum mary}

The article is an attempt to determine whether the reasonable man standard used in criminal law constitutes a uniform category. The author concludes that this figure is applied on two basic levels: (i) to determine the perpetrator's consciousness of actus reus, and (ii) to define the duty of care, including reasonable foreseeability. This observation makes it possible to distinguish two basic types of the aforementioned standard, which differ from each other not only in the subject of the reference but also in their internal structure. 
